\title{
Sales Channel as a Strategic Choice - SME Managers Seeking Profitability
}

\author{
Lejla Karamehmedovic ${ }^{1} \&$ Krister Bredmar ${ }^{1}$ \\ ${ }^{1}$ School of Business, Economics and Law, University of Gothenburg, Sweden \\ Correspondence: Krister Bredmar, School of Business, Economics and Law, University of Gothenburg, Box 610, \\ S-405 30 Gothenburg, Sweden. Tel: 46-31-786-6948. E-mail: krister.bredmar@gu.se
}

Received: April 23, 2013

Accepted: May 27, $2013 \quad$ Online Published: June 14, 2013

doi:10.5539/ibr.v6n7p1

URL: http://dx.doi.org/10.5539/ibr.v6n7p1

\begin{abstract}
The development of various types of sales channels has increased interaction opportunities between corporations and end users. Furthermore, customers have gained increasing influence in business due to the development of performance measures as customers' ability to influence corporate profitability has gained importance in economic governance. This affects today's business leaders' strategic decisions because they need to decide which marketing channels they should use to reach out to end users and how they should proceed in order to increase customer profitability. The purpose of this study is to identify the driving forces behind the strategic choices of the sales channel(s) and to describe the managers' views of the customers behind the marketing channels and how satisfied, loyal and profitable these customers are. The strategic choices and motivations behind the choice of sales channels are characterized partly by managers' personal experiences and views on the channel opportunities, coincidences and the fear that some channels will compete with each other. The majority of the managers believe that customers behind sales channels have different preferences, but they use no analysis of how satisfied and loyal their customers are. Satisfaction and loyalty are factors that should be analyzed because they are assumed to lead to customer profitability.
\end{abstract}

Keywords: sales channel, physical store, retailers, direct trade, e-commerce, combined sales, customer satisfaction, customer profitability

\section{Introduction}

In today's society, companies constantly need to evolve asthe demands to cope on the competitive market are high (Kylebäck, 2007; Howell \& Soucy, 1990). The number of companies choosing to focus on e-commerce as a sales channel is ever increasing, but there are still many companies that prefer to focus on store sales, direct marketing or mail order. One sales channel does not exclude another, which is evident in the market as multiple sales channels become more common (Neslin, Grewai, Leghorn, Shankar, Teerling, Thomas \& Verhoef, 2006). Sales channels differ in various respects, each with their advantages and disadvantages. There is no definite answer to which sales channel is the best, but there are many theories about what may be true in the future. One of these theories is that companies only using one sales channel do not have sufficient competitiveness against companies using multiple sales channels (Porter, 2001; Wolk \& Skiera, 2009).

As companies open up more sales channels they provide greater accessibility for consumers. Compared to a few years ago, location and time now have much less effect on trade. Consumers are free to choose where and when they want to do their purchases (Bergström, 2007). In combination with increased globalization, this leads to the fact that businesses no longer compete on a local basis, but the competition for customers occurs between all companies that offer similar products or services. This has led to a power shift from companies to consumers (Söderlund, 1997; Bergström, 2007).

It is not only in this regard that consumers have gained more influence on companies. Considering financial performance measures, customers and their impact on a company's profitability have gained greater focus in the accounting context. Previously, companies mainly focused on increasing customer value to as many customers as possible, but since 1980 there has been a shift to a greater focus on specific customers rather than customers in general (Boyce, 2000). This development is mainly due to greater awareness among companies about costs and benefits and that these will vary between customers. By determining how profitable customers are on an individual or segmented level, companies can discard customers whose costs are higher than their revenues 
(Kaplan \& Cooper, 1998). Loyal customers are assumed to bring a number of benefits in the long run, which will lead to higher profitability compared to customers who are not loyal to the company (Söderlund, 2003;Oliver, 1999). For a customer to be loyal, the company first and foremost needs to satisfy the customer. Customer satisfaction is based on the consumers' individual aspects; thus companies need to consider what factors they have that will satisfy customers (Day, 1977; Söderlund, 1997).

In light of this reasoning, it is interesting to describe how different sales channels are used by small businesses in a cyclical industry, and also to describe managers' views on the relationship between customer satisfaction, customer loyalty and customer profitability. The goal of this study is to describe how the manager works strategically with sales channel management as a tool to achieve as high profitability as possible. The relationship between the manager's understanding of the sales channel and ultimately the strategic perception of the profitability of the combination of sales channels is the focus of the study.

\section{Literature Review}

Corporate interactions with customers take place in many different ways and through different channels. It is increasingly common for companies to use multiple sales channels. Companies can either integrate with the end consumer via retailers or interact directly with the end consumer through Internet access, telephones, ATMs, kiosks, catalogs or physical stores (Neslin et al., 2006). The most common sales channels in Sweden are physical stores, direct marketing and catalog sales, which includes mail order and e-commerce.

\subsection{Store Sales}

Running a store is associated with a range of costs and revenues, and according to Hernant and Boström (2010) there are five key factors that determine whether a store is profitable or not. These are location, product selection, price, service and communication. Being successful in these key factors results in both satisfied customers and a strong competitive advantage for the company. Store location is the main competitive advantage, partly because it states the stores availability but also because it is a unique feature that cannot be copied by competitors. Product assortment and prices are of great importance for the economic outcome, as these will determine which customers will shop and contribute to revenues that will cover the costs. Service and communication with consumers is also of great importance as they contribute to an overall picture of the store (Hernant \& Boström, 2010). Bell, Ho and Tang (1998) also believe that the preference of one store over another is affected by preference to the store and how loyal the customer has been in the past.

Some of the advantages of a physical store are that the end consumers have the opportunity to touch the product, they can immediately bring the product home and they can also meet other customers via customer-to-customer-related activities that the stores arrange. The main advantage is that the employees at the store have a great opportunity to influence the satisfaction of a customer directly in the shop. This can be done either by employees recognizing the customer, or by directly recalling to the customer's previous purchases or by taking care of complaints on site. To enable this, it is essential that employees thrive at work (Hernant \& Boström, 2010).

\subsection{Retailers}

Because the retailers have the main contact with the end consumers, it is important that the supplier is aware that the retailer is the one who represents the brand towards the end consumer (Glynn, Motion \& Brodie, 2007). Having a good relationship with retailers will therefore be crucial for the companies' success. The better the relationship between the supplier and the retailer, the greater competitiveness for both companies (Powers \& Reagan, 2007; Morgan \& Hunt, 1994). At the beginning of the relationship, rumors will play a major role because the company has no previous experience that can determine whether the other party is truthful (Powers \& Reagan, 2007).As the relationship between the companies develops, confidence will be essential. Trust between the parties also leads to a long-term relationship (Morgan \& Hunt, 1994).

\subsection{Direct Trade}

The most common form of direct marketing is done via home parties, but direct trade also occurs in other forms such as telemarketing and seminars. One of the direct trade advantages is that costs incurred in the intermediate between wholesalers and retailers, like warehousing and transportation, are reduced. (Bergström, 2007). This is due to the fact that the direct seller for a home party orders the goods that the consumers demand, either directly from the manufacturer or through the direct sales company. The direct seller has taken the dealer's role, but without the cost that the dealer has (Peterson \& Wotruba, 1996). Since the direct sellers represent the brand towards the end consumer, they will be the company's key customers (Berglund, 2007a).

Consumers today often demand more than just the product or service itself; they also look for experiences 
(Mossberg, 2003). Bergstrom (2007) argues that the main advantage of direct trade is its ability to create experiences for consumers. These experiences are created in the consumer's home where consumers can both receive personal service from the direct seller and socialize with each other. Another advantage of direct trade, according to Berglund (2007), is that the recruitment of direct sellers often cost neither time nor money because many of the direct sellers begin their careers as customers of the company or by recommendation from other direct sellers.

\subsection{Electronic Commerce}

The definition of e-commerce differs as this type of trade can be viewed from different perspectives. First, it is seen as a business process in which technology is used to automate workflows and business transactions. It can also be seen from a communication perspective, a sales perspective and a service perspective as electronic commerce enables faster and more efficient service (Kalakota \& Whinston, 1996). As trade over the Internet is neither dependent of time nor place, it enables companies to increase revenues by selling more to existing customers and to attract new customers (Peterson, Balasubramanian \& Broonenberg, 1997; Rohm \& Swaminathan, 2004). Attracting new customers is easier because the Internet expands the company's market reach and makes the company available to a larger group of people (Srinivasan, Anderson \& Ponnavolu, 2002). In addition, the Internet has the ability to store large amounts of information in an inexpensive and time efficient way (Peterson et al., 1997).

As information becomes more readily available to consumers, it increases the communication between consumers and companies, which can strengthen their relationship (Hoffman \& Novak, 1997). However, it also increases competition between companies as information of competing companies' products, prices and conditions are only a few clicks away. This increases the possibility for consumers to compare different options compared to other sales channels (Srinivasan et al., 2002). Since price is the factor companies mainly compete with, it has led to a decline in various sectors' profitability. In order to not only compete with price, companies need to create something unique that consumers demand and that other companies cannot copy (Porter, 2001).

The introduction of e-commerce raises both strategic and operational risks. The operational risks include failure of the Web, that customers' orders get lost or delayed, or the risk of someone hacking into the system accessing information about the company and their customers. The strategic risks include, among other things, wrong decisions on electronic investments (Chaffey, 2007). Porter (2001) believes that companies in today's society will not be able to survive in the competitive market without the use of electronic commerce.

\subsection{Combined Sales}

A challenge that may arise from the implementation of additional sales channel is the handling of data integration between sales channels. Managers also need to have an understanding of customer behavior, i.e., what channels they choose and why. The next step is to evaluate the different sales channels. Questions about what additional sales channels may provide needs to be taken under consideration. Business leaders need to go beyond this to allocate resources between sales channels and coordinate goals and strategies to create synergies across the sales channels (Neslin et al., 2006).

In December 2000, Mahajan and Wind (2002) conducted a study of 48 successful e-commerce companies that managed to survive at a time when many other companies had to shut down their Internet-based activities. The successful companies all used multiple sales channels, which suggests that it is essential for customers to communicate with companies in various ways. The use of multiple sales channels prevents businesses from having to rely on one kind of customer and his preference of sales channel, and it can also enhance both customer relationships and brand.

Combined sales channels lead to higher customer profitability as the ability for customers to choose among multiple sales channels contributes to both higher customer satisfaction, customer retention and customer growth (Venkatesan, Kumar \& Ravishanker, 2007; Wallace, Giese \& Johnson, 2004). The primary reason for the increase in profitability is that customers feel that companies have a higher level of service awareness when they have multiple sales channels. Enterprises can offer additional services between the different sales channels, so that consumers are given the opportunity to order online and then pick up the product in a store, which increases the consumers' options (Venkatesan et al., 2007). According to Gensler, Dekimpe and Skiera (2007), customers who generally spend more money and make more frequent purchases prefer to use multiple sales channels. In addition, customers using multiple sales channels spend on average 20-30 percent more money compared to customers who only use one sales channel (Myers, Van Metre \& Pickersgill, 2004).

There has been much speculation regarding the fact that the implementation of additional sales channels can 
impair for initial sales channels. Wolk and Skiera (2009) mention that the lack of knowledge about how the combination between different sales channels should be done can be difficult to process and may cause difficulties for the company in the future. In addition, companies with combined sales channels encounter difficulties with satisfactory customer service and customer retention, which can lead to a decrease in customer loyalty (Coelho, Easingwood \& Coelho, 2003). Despite these negative aspects, most of the research done in this area concludes that further sales channels are complementary (Neslin et al., 2006).

\subsection{Customer Satisfaction - Customer Loyalty - Customer Profitability}

There is a known relationship between customer satisfactions, which leads to customer loyalty, which in turn leads to customer profitability (Helgesen, 2006). Companies strive to have as satisfied and happy customers as possible. There is no distinct view which is widely accepted among scientists how customer satisfaction is achieved, but many agree that it is based on subjective expectations, either achieved or unachieved (Oliver, 1980; Yi, 1990; Day, 1977; Söderlund, 1997). It is important both to put customer satisfaction in relation to what factors it is caused by and to consider if these factors can be influenced by the company or not (Söderlund, 1997). Companies, for example, do not have an equal opportunity to influence a client's life situation. If the consumer's satisfaction, on the other hand, is affected by the product, the shopping experience, the purchase decision process, the hospitality of the staff and seller or the store design, companies have a greater opportunity to perform actions that could increase customer satisfaction (Söderlund, 1997; Yi, 1990).

Customer satisfaction can be seen as a state in the customer's head based on the customer's subjective assessment, whereas the actions that result from the customer's level of satisfaction can lead to both loyalty and profitability for the company (Söderlund, 2003). But customer satisfaction does not automatically lead to a loyal customer since customer can be satisfied with a purchase without being loyal to the company (Söderlund, 1997; Söderlund, 2003; Reich Held, 1988; Hernant \& Boström, 2010). Loyalty can be expressed either behaviorally or attitudinally. Behavioral loyalty mainly affects the rate of visits made by the customer, the repurchase rate and the revenues that the customer will contribute to the company. It is mainly this type of loyalty that generates revenue in the short term. Attitudinal loyalty, on the other hand, focuses on how confident the customer feels about the brand and how committed the customer is towards the company. Customers displaying both behavioral and attitudinal types of loyalty are ideal for companies. (Hernant \& Boström, 2010).Loyal customers do not require the same amount of resources to maintain satisfied compared to customers who are not loyal. However, companies must be aware that even loyal customers can be dissatisfied. It is therefore important that companies always try to amend the loyal customers' dissatisfaction because it can lead to increased loyalty and reduce the risk of negative word-of-mouth (Jones \& Sasser, 1995; Söderlund, 1997).

The single most important factor for long-term economic development is loyalty, because the more loyal a customer is, the more profitable he or she is to the company. This is due to the impact loyalty has on increasing revenue and reducing costs (Reich, Held \& Sasser, 1990; Gremler \& Brown, 1999). It is therefore essential to identify which customers are profitable in order to focus more resources on them while considering which customers cost more than they contribute to the revenue (Jones \& Sasser, 1995). However a new customer can cost up to ten times more than retaining an existing customer. This contributes to the evaluation of how existing customers can become more loyal (Davis, Brodie, Lindgreen \& Buchanan-Oliver, 2000).

Profitability analyses can be made onan individual level, a segmented level or based on the customer's lifetime. In a theoretical context, individual profitability analysis is the most common (Guilding \& McManus, 2002). To perform a thorough cost-benefit analysis at individual customer level, detailed information on the incomes and expenses incurred between the company and the customer are required. Revenue is primarily based on the price the company takes for the product or service, while the cost arises when the customer uses the company's resources (Foster, Gupta \& Sjoblom, 1996). It is not difficult to identify the income a customer contributes to, but it is more difficult to identify the costs associated with the customer as they are often seen as overhead costs. Customer Profitability Analysis at individual level therefore clarifies to what extent each customer consumes the company's resources, creating opportunities for companies to control costs, make better decisions about prices and discounts and segmenting customers (van Raiij, Vernoiij \& Trist, 2003).

According to the theoretical framework, there are both advantages and disadvantages to the different sales channels and the combination of them. There is no definite answer to which sales channel is the best or whether multiple sales channels actually contribute to a competitive advantage for companies. It is up to each company and its managers to make decisions about which marketing channels they should use. Since people have different preferences, the customers behind the sales channels differ. Managers need to be aware of who these customers are, and whether they are satisfied with the company or not. As Kaplan and Cooper (1998) discuss, the customers 
have different impacts on a company's profitability. By analyzing which customers are profitable, companies can focus on the most profitable customers instead of wasting resources on unprofitable customers. Loyalty is considered to be a contributing factor in increasing customer profitability. Customer loyalty is greatly affected by how satisfied customers are, and as mentioned above, there are various factors that affect customer satisfaction.

\section{Methodology}

An industry that is constantly evolving and where competition between firms is large is the clothing industry. Furthermore, clothes are products that can be sold across various sales channels, which makes this industry well suited for a study of the problem issues. The clothing industry is a major industry in which companies sometimes choose to invest in marketing to a specific audience. Within the industry, children's clothing has grown dramatically in recent years. The number of Swedish companies active in the sales of children's clothing has also increased, especially in the last fifteen years. In the selection of companies, the following criteria were essential. Firstly, it was important that companies were both founded and currently active in Sweden since the study only concerns this market. In addition, companies were chosen depending on which distribution channels they use as there had to be a balance between the four sales channels discussed in the study. Finally, the companies should not have been established before 2003. This distinction was made to lessen the age differences between the companies so that the outside worlds' influence through the development of such things as technology would not differ too much.

Another important criterion was that the respondents had been involved in the start-up phase of the company and were still active in the company. This enabled an overall picture of their thoughts on both sales channels and customers during the start-up phase of the company compared to the current situation. Nine companies were selected, and respondents were interviewed on-site or by telephone. The interviews were semi-structured so that the respondents had the opportunity to share their individual views on sales channels and consumers. The personal interviews were recorded with the consent of the respondents. This enabled a greater focus on the interaction with the respondents because no notes had to be made during the interview. After the interview, the material was transcribed, and the most relevant parts were selected and presented in the results. Telephone interviews, on the other hand, could not be recorded because this facility was missing. Instead notes were made during the interview, which the respondents were aware of and showed great consideration for. The respondents also repeated relevant and essential parts of the interview so that no misinterpretations would be made.

\section{Results}

\subsection{Corporate Presentation}

Cloo Collection was founded in 2011 by Maria Lofjärd. Initially, Maria had two investors, which allowed her to buy a first set of garments that she sold via an online store. Through the online store, she was contacted by a few retailers, but she also contacted some retailers herself. Maria currently runs Cloo Collection alone, and she has a part-time job that she intends to keep until her company gets bigger.

Two sisters, Anna Rietz and Sara Marmsjö, founded Geggamoja in 2008. Geggamojas history, however, started already in 2006 when Anna started a thrift shop where she sold self-designed children's clothing. Interest in the garments grew rapidly, and retailers contacted Anna wanting to sell her clothes. In 2008, the demand for the garments had increased significantly, and therefore Anna and Sara chose to invest wholeheartedly in the company. Geggamoja currently uses retailers, physical stores and e-commerce as sales channels.

Anna Nordqvist founded Lobilo in 2010, and she currently runs the company on her own. In the startup phase, Anna used a website where end users could email her if they were interested in buying her products, though it was not a real online store. Making use of retailers was Lobilo's first major sales channel. Usually, the retailers contact Anna about selling her products, but sometimes Anna contacts retailers situated in areas where she wants to sell her products. Currently, she is in the process of starting up an online store as a second sales channel.

Lundmyr of Sweden was founded in 2004 by Mia Lundmyr. Making use of retailers was an obvious choice for Miaas she wanted to sell high volumes right from the start. After a few years, she created a website where retailers could place their orders. The website was developed so that end users could buy directly from Lundmyr of Sweden. Today Ludmyr of Sweden has seven employees.

Me \& I was founded in 2004 by Susan Li Engvall and Helene Nyrell. Both Susan and Helene wanted to do something big, be in charge of their own time and handle all the distribution themselves. Therefore, they chose to focus on the sale of children's clothing through home parties. In the autumn of 2004, they had 30 direct sellers all over Sweden, and today they have over 750 direct sellers in Sweden, Norway, Finland, England and Germany. In 2010, they also chose to start a web outlet where they sell the residual range from previous 
collections.

My Only is a new company that started in April 2012. The founders are Åsa and Andreas Jonsson, who wanted to start a business together. Both Andreas and Åsa have jobs besides My Only, but their goal is for Åsato be able to work full time with My Only as the company grows and gets more retailers. In addition to retailers, they also have an online store and occasionally arrange home parties.

Nova Star is a family business run by Helena Orlenius, Lovisa Aldero, Christer Aldero and their families. Helena sewed clothes for her own children and friends, and soon retailers became aware of her clothes. Consequently, she started to make clothes for retailers and founded Nova Star in 2004. When the second collection was launched, she took the help of her sister Louise and her family. Nova Star only uses retailers as a sales channel, and they currently have over 100 retailers in Sweden.

Malin Broomé founded Rabdido in 2006. In that same period, the situation for small stores focusing on children's clothing was tough in Sweden because big chains like H\&M and Lindex started producing more children's clothing. Meanwhile, direct selling was a new hot trend with few market players. Malin chose to invest in home parties as an initial sales channel. In addition, Rabdido now also has a web outlet where residual stock from previous collections are sold. Three full-time workers on Rabdido assist Malin.

Rockefella was founded in 2007 by Sofia Renck and Wenche Özdemir. Sofia and Wenche wanted to build something from scratch and also create a well-known brand. Both Sofia and Wenche are active in the company, and they are assisted by additional staff who work in the store in Stockholm when necessary. Currently, Rockefella are using retailers and physical stores as sales channels. They have also had a web shop, which they chose to close.

\subsection{Physical Stores}

Out of the nine companies that participated in this study, only Geggamoja and Rockefella use physical stores as a sales channel. Both Geggamoja and Rockefella have two stores each, one of which is adjacent to their stock, while the other is located in central parts of Stockholm.

Rockefella's physical stores have evolved over the years. They were in need of an office and a showroom in Stockholm and chose to use the premises fully as a shop for end consumers. The shop displays the entire collection for the end user, as opposed to retailers who usually only have a smack selection to display. The physical stores are also used to sell the products that the retailers are not interested in buying. The second store is located in relation to their warehouse and mainly works as an outlet.

According to Geggamoja, the stores are no cash cows. The store in central Stockholm basically works as a promotional window. Geggamoja chose to have retail sales through their own stores as they get the opportunity to showcase their entire collections to consumers who prefer to shop in stores. Moreover, the advantage of having a retail store is that customers pay directly, unlike retailers who usually have 30 days to pay. It is the end consumer who has contributed to Geggamoja's good liquidity. According to the founders, another advantage, is the possibility to directly interact with the end consumer through physical stores. Anna and Sara believe that they learn a great deal from the end consumer in comparison to the information they get from the retailers. They get a closer relationship to the customer without the intermediate step of using other sales channels.

The majority of the remaining respondents feel it would be fun to run their own store in the future. Both Mia Lundmyr and Susan Li Engvall mention that they are interested in having a flagship store in a major city to show off their brand. Mia Lundmyr mentions that the benefit of a physical store is the ability to experiment before a new collection is released, to see if the products will sell before they are produced. The store can also provide inspiration for retailers on how to expose the brand in the best way. In addition, the company has direct contact with the end consumer, which gives them and the end user quicker feedback. However, Mia Lundmyr mentions that it might be bad PR if the store has to be closed down.

Neither Maria Lofjärd nor Christer Aldero saw physical stores asa potential initial sales channel, primarily because the supply of clothing is very small in the beginning. Physical stores also require lots of time, effort and energy according to Christer Aldero. Maria Lofjärd mentions that there are significant risks and costs associated with a store. Storestie much capital as high rents, administrative work and staff expenses, which means that the company always have high costs. This view is shared by the other respondents, and this is seen as the main reason why physical stores have greater risk than other sales channels. Anna Nordqvist mentions that an increasing amount of retailers have been forced to close down their shops, which she thinks indicates that it is a risky time to start a small physical store.

An additional negative aspect mentioned by respondents is that physical stores are very time consuming. Susan 
Li Engvall states that there would be no opportunity to control her own time as staff always needs to be on site during the store's opening hours. Andreas Jonsson thinks it is difficult to succeed in running a successful store without a strong brand. An awareness of the brand must first be built before it can be worthwhile to open a store. Malin Broomé is the only respondent who have no interest in opening her own physical store in the future. This is mainly because she does not believe that it is possible to have a physical store of clothing and still keep low prices. The store will contribute to an increase in prices on the clothes, which in turn could possibly lead to a loss of customers.

\subsection{Retailers}

All respondents, except Rabdido and Me \& I, use retailers as a sales channel. One of the advantages of retailers is the opportunity to sell high volumes quickly. For Mia Lundmyr, the use of retailers was an obvious choice even from the beginning because "... they buy larger quantities and invest more. If you have ten retailers and they buy 48 pieces each, the total amount will be 480 pieces. If you have ten end customers, who buy one item at the time, only ten garments will be sold."

An additional benefit of retailers is their ability to reach out to a wider clientele. Anna Nordqvist mentions that she would never have been able to reach out to as many end users in such a short time on her own. Andreas Jonsson believes that My Only's biggest challenge is to take a position on the market. They want as many retailersas possible so that the retailers can help My Only to reach out to a larger customer base. Retailers reach out to more customers and consequently create brand awareness.

Maria Lofjärd believes that it is convenient for consumers to use retailers as a sales channel as they can purchase different brands in the same place. She also mentions that the uses of retailer' are tampering with the margins as the retailers demand reduced prices on the clothing. Maria views this cost as a marketing cost as retailers help to market the products to both end users and other retailers. Maria mentions that many of Cloo Collection's retailers have contacted her after seeing that other retailers are selling her products.

Nova Star only uses retailers as a sales channel. This is mainly because they do not want to compete with retailers by using additional sales channels. They also want to be the best suppliers for their retailers, because then they feel that the retailers become more loyal and satisfied towards them. Nova Star chooses to stock products for the retailers, which means that retailers do not take any risks because they do not have to buy large stocks of Nova Star clothes. Instead, they can restock when they need to. This is, on the other hand, a risk for Nova Star. They have noticed that many retailers have sold out their products, but do not restock because they have no obligation to purchase their products.

Anna Rietz and Sara Marmsjö mention that there are retailers who buy much of their range, but there are also those who only buy hats and bodysuits. Those who buy a pinched supply still require both time and attention from Geggamoja. According to Sara, it may be that "a small retailer uses more resources than it gives." Anna and Sara also believe that companies who only use retailers have restricted contact with end consumers. They do not believe that the big retailers know who their customers are because they often offer a wide range of products. This means that Anna and Sara do not get proper feedback from retailers about who Geggamoja's end customers are.

Rabdido and Me \& I have chosen not to use retailers as a sales channel. What is common to these companies is that they both primarily use direct trade as a sales channel. Me \& I have chosen to abstain from retailers because they wanted to have control over the distribution and be independent. For Rabdido, retailers have not been relevant in the past, but in recent years they have discussed the use of retailers more because they want to reach out to more customers. Therefore, using retailers as a sales channel could definitely be of interest for Rabdidoon the foreign market, but not in Sweden as they do not want to compete with the existing sales channels.

\subsection{Direct Trade}

Me \& I and Rabdido have direct trade with a focus on home party as their primary sales channel, while My Only use home party as a temporary supplement to other marketing channels to spread awareness of the brand in the early stages of the company. Susan Li Engvall believes that the great strength of direct selling is its services as direct sellers act as personal shopping assistants for their customers. They help the end user to find the right products in relaxing conditions where customers can shop and socialize with other customers when they have time. Malin Broomé believes that parents are very stressed, which makes home parties a good sales channel. Susan Li Engvall also mentions that Me\&I does not have to spend money on marketing because they have over 750 vendors in five countries that constantly market them with positive word-of-mouth.

For both Rabdido and Me\&I, one of the most essential parts of direct trade is that the direct sellers are suitable 
for the work. Susan Li Engvall mentions that since day one it has been important to Me\&I that the direct sellers are "the right girls, trendy and hot moms that people in the neighborhood want to be associated with." This is because they convey the brand Me\&I as hot and trendy. Malin Broomé thinks it is a tough challenge to recruit good sellers, especially in those parts of the country where they usually do not operate. Another disadvantage, according to Malin, is that she as a manager often acts as a hobby psychologist for the sellers who do not do particularly well. She is unsure if these direct sellers have chosen to work with home parties because they enjoy selling the clothes or just because they need someone to talk to about their everyday problems.

Malin Broomé also believes that it is difficult to determine who your customers are and what they will buy because that depends on whom the direct seller has gathered for the home party. This makes it difficult to determine the quantities they need to buy of each size. Moreover, it is difficult to predict which designs will be popular and which are not going to sell. Susan Li Engvall also believes that it is difficult to retain the customers if the customers' direct seller chooses to quit. When a direct seller at Me\&I chooses to leave the job, they have the option to choose between giving up their customer lists to Me\&I or to keep it. If the direct seller chooses not to hand over the customer data, there is a major risk that Me\&I will lose these customers. That is, if the end users do not choose to contact Me\&I on their own. Rabdido, on the other hand, always has access to the direct sellers' customer database. This means that if a direct seller decides to quit, Rabdido can contact the direct seller's customers and offer them a new sales representative or inform about their web outlet.

Maria Lofjärd, Mia Lundmyr and Anna Lundqvist all mention that direct trade of children's clothing through home parties has proven to been a successful concept. Despite this, none of them would like to make use of direct trade as a sales channel mainly because they would not be able to participate in a home party themselves. Mia Lundmyr and Sofia Renck mention that they chose not to invest in direct sales because they have lack of knowledge of the sales channel. Maria Lofjärd mentions that she feels "personally uncomfortable to create a situation where people feel pressured to buy." However, Maria's investors like the idea of investing in home parties through direct sellers in areas where Maria does not operate. The focus would then mainly be on big cities. Direct sellers would sell on commission, which is convenient as Maria would not have to take any big risks. Malin Broomé mentions that Rabdido has not been successful in big cities such as Stockholm, Gothenburg and Malmö. Instead, home parties for Rabdido have been more successful in small towns.

\subsection{Electronic Commerce}

The majority of the respondents who use electronic commerce as a sales channel offer their entire range to the end consumers via an online store. Rabdido and Me\&I only offer parts of their range via a web outlet, and Nova Star refrain entirely from conducting sales online. According to the respondents, the key benefits of electronic commerce is the higher income that arises when sales are made directly to end consumers because they pay full price for the products, unlike retailers who want a margin on the products. According to Mia Lundmyr, the online store also works as a good tool that shows what customers buy. By using the online store as a customer base, they can see how many customers in a district purchase a particular garment. With this information, they can advise retailers in that area which garments they should stock.

Although the online store is the sales channel that gives the highest margin for suppliers, both Anna Nordqvist and Andreas Jonsson state that an online store is not enough to reach the volume of clothes needed to be profitable. Maria Lofjärd finds it difficult to justify to customers why they should buy from Cloo Collections online-store as the price is the same at the retailers, but with less choice for the consumers. Christer Aldero and the others at Nova Star have thought about opening an online store, but still choose not to do so. They are aware of the benefits, such as the ability to present the entire collections to the end consumers and the higher availability to customers. However, they believe that it will affect the retailers negatively because they will probably not sell as much. Malin Brooméis aware of the advantages with an online store; however, she is confined with having a web outlet with products that do not sell on the home parties. The full range is not available on the online store because she claims it is important to maintain the exclusivity of home parties.

Me\&I also uses a web outlet in order to empty their inventories for the coming season. Before the web outlet opened up, they used sales and promotions on the home parties to sell their residual stock. There is an ongoing debate whether or not they should open an online store which offers Me\&Is full range. It would not cost much money or time in comparison to the income that is likely to occur via an online store. However, there are some negative aspects of electronic commerce for Me\&I. Some of these are the fear of competition with the direct sellers, and that the online store requires much higher marketing costs compared to other sales channels. The 750 direct sellers constantly talk about Me\&I in a beneficial way without any big expenses. Susan Li Engvall believes that the web requires constant advertising. When they advertised about their web outlet, the number of 
visits increased the next few days and then returned to normal. Therefore, companies constantly need to advertise to attract customers online, which is associated with high costs.

Sofia Renck and Wenche Özdemir used a shop at the startup of Rockefella. They found the website very messy to control, however, and much effort was required to make it work properly. It requires, among other things, a good ordering system, good payment system, good service, and that the company is high on Google's search engine optimization. That was too much for them to steer with, which lead to the closing down of the web store and the entire focus on retailers as a sales channel. As their retailers have famous and popular online stores, they felt that it was better to leave the Internet stores to the retailers who know what it takes to make it work.

\subsection{Customer Satisfaction / Customer Loyalty / Customer Profitability}

As the competition today is tough, Sara Marmsjö believes that companies need to have loyal customers to succeed in what they do long term. Maria Lofjärd also sees loyalty as an important part of her business, and believes that by having satisfied customers, she will have loyal customers. Anna Nordqvist does not believe in loyal customers because she considers that consumers will shop where it is easiest and best for them. To get returning customers it is important for her that the customers are familiar with the brand and that it is convenient for them to shop at the online store. If the customers were satisfied with the shopping experience once, they will be more likely to return. Anna Nordqvist thinks it will be easier to know who her customers are via the web system, in comparison with the feedback she receives from the retailers as they can only provide information on the best-selling garments. As her online shop is small, Maria Lofjärd feels that she is able to keep track of who her regular customers are, because she recognizes their names in her system. Even Sara Marmsjö and Anna Rietz use the web system as a tool for evaluating how satisfied and loyal their customers are. Through Google Analytics, they can see that 60 percent of their customers are repeat customers, while the remaining 40 percent are new customers. However, they do not know if these customers actually buy anything, or if they just look around the website. Therefore, in order to improve their operations, they would like to examine how satisfied and loyal their customers are and what factors affect the customers to make a purchase or not.

At Me\&I, the stories told by children, customers and the direct sellers about the clothes work as a measure of customer satisfaction. They use these stories in their marketing towards both prospective direct sellers and end consumers. They assume that what makes their customers happy are the clothes' high quality, unique design and the expression that the clothes have. Even though they find the stories helpful, they would still like to measure and analyze information about their customers. This is not done today. Susan Li Engvall believes that customers are becoming more and more discerning, and that it would be nice to offer consumers customized offers based on what they have purchased in the past or what they have looked at but not purchased.

Christer Aldero, on the other hand, knows that Nova Star does not need any surveys or measurements of how satisfied and loyal their customers are because they are close to both end users and retailers, in comparison with, for example, bigger companies like H\&M or Peak Performance. Christer rather believes that it is all about the manager, and that he or she must believe in the brand and be able to sell it. Malin Broomé is also skeptical to measurements of customer satisfaction and loyalty because she questions how the measurements should be carried out and if it can be ensured that the measurements are correct. In order to keep customers happy, Malin believes that the company must be sure to have high quality clothes, and quickly fix problems if something goes wrong: "No negative goodwill should exist among the customers; the goal is to create a wow feeling among customers. However, sometimes things go wrong due to human error, but when that happens, it is important that the dissatisfied customer is taken care of so that he will be as happy as possible to avoid unhappy customers who spread bad will". If the customer is happy, he will return to Rabdido. Through their web systems and direct sellers, Malin knows that Rabdido have many returning customers.

\section{Discussion}

Although traditional store sales is by far the largest sales channel in Sweden, only two of the companies use this channel, Geggamoja and Rockefella. Among the other respondents, there is a concern about the great risks and costs associated with physical stores. The use of retailers as a sales channel is a common phenomenon. Retailers assist with other marketing channels where they have contact with the end consumer. When companies use resellers, relationship is essential as a good relationship benefits both parties (Morgan \& Hunt, 1994; Powers \& Reagan, 2007). This is particularly evident in the Nova Stars case where they waive the use of multiple sales channels to not compete with their retailers. Business relationships can be both good and bad, which is evident in that Geggamoja did not get any support from their retailers on an idea they had great confidence in and that also proved to be demanded from the end consumers. Making use of home-party as a sales channel is not that common, and direct trade accounts for a small proportion of total sales in Sweden. When companies use direct 
trade, the direct sellers that arrange the home parties are the individuals who represent the brand for the end consumer, like the use of the retailer. The most valuable resource for this type of sales channel will therefore be the direct seller. This is the reason why both Me\&I and Rabdido, companies that use home-party as their primary sales channel, put great emphasis on recruiting the right sellers. Electronic commerce is the sales channel that is constantly increasing in Sweden, and researchers claim that companies in today's competitive market will not manage without being available on the Internet (Porter, 2001; Peterson et al., 1997). The development of electronic commerce is greatly influenced by the development of technology, which indicates that this sales channel will develop even more in the future. In the past, however, the end consumers' attitudes towards new technology have not always been positive (Rådmark, 2009).

According to Porter (2001), it is essential for today's businesses to operate on the electronic sales channel. However, this is the sales channel that the majority of the respondents see as the greatest risk. The electronic sales channel removes intermediaries like retailers and direct sellers and directly addresses the end consumer in the same way as physical stores do. Managers see a concern from retailers and direct sellers that a web store competes with the same range as the retailers offer. Christer Aldero believes that the introduction of an online store for Nova Star would mean losing valuable retailers. However, all respondents except Nova Star and Rockefella, use both retailers and e-commerce as sales channels, without considering it as a drawback. Mia Lundmyr, Sara Marmsjö and Anna Rietzall felt that their retailers were initially worried that multiple sales channels would increase the competition between the sales channels, but after the enforcement, they do not see any problems with the use of multiple sales channels.

From the managers' perspective, reaching out to a wider public and thus learning more about the market they operate in, is what they expect will contribute to a higher profitability for the company. These benefits are also found in theoretical contexts. Venkatesan, Kumar \& Ravishanker (2007) argue that companies who use multiple sales channels are considered to have higher service awareness. This is in contrast to Coelho, Easingwood and Coelho's (2003) view that multiple sales channels can lead to increased pressure on the company regarding its service, which can lead to a lack of customer satisfaction. The main concern from the managers' perspective is the risk of cannibalization between the channels. From a theoretical perspective, the use of multiple sales channels are assumed to be beneficial for the company. Wolk and Skiera (2009) argue that the difficulty for companies using multiple sales channels is lack of knowledge. Sofia Renck and Wenche Özdemircan certify this as they chose to shut down Rockefella's electronic shop because they could not handle the channel as they wished.

Although the majority of the respondents believe that satisfaction and loyalty are essential, no research has been done about how loyal and satisfied the companies' customers are. For companies to identify their profitable customers and cut costs on customers who are unprofitable, it is considered necessary for the companies to conduct research about their customers (Jones \& Sasser, 1995). Both Christer Aldero and Malin Brooméquestion if information on the satisfaction and loyalty of customers is beneficial for the companies' future. The majority of the respondents argue that they get enough information from either their online store or through feedback from retailers or direct sellers. One of the main advantages of e-commerce is considered to be the ability to store large amounts of information (Peterson, et al., 1997). Respondents seem to exploit this advantage, however, primarily to identify who their returning customers are. They do not use this information to examine what factors affect their customers' satisfaction and loyalty. A customer may be loyal and make repurchase, and still become unsatisfied and start spreading negative word-of-mouth (Söderlund, 1997).

\section{Conclusions}

Based on the nine interviews conducted with managers in the clothing sector, whose main products consist of children's clothing, it became clear that there were different strategic ambitions and motivations behind the choice of sales channels. All managers motivate their choice of initial sales channel either as a coincidence or as a personal preference. The problem seems to occur when the managers need to decide whether or not to open up for additional sales channels. The fear that the combined sales channels compete with each other are often large, despite the fact that the use of multiple sales channels, based on a theoretical context, is seen as a competitive advantage for companies. The companies who have opened additional sales channels despite concerns over competition are now in favor of the combination of channels, primarily because they are able to reach out to end consumers through various channels.

Based on the respondents' personal experiences and the theoretical framework, it is obvious that there are both advantages and disadvantages with each sales channel discussed in this study. It is noticeable that the mentioned sales channels all offer something unique. The use of physical stores is seen as beneficial because it promotes the 
personal contact between the company and the consumer, particular regarding service and inspiration. Retailers are unique because they offer a wider range to a larger customer base compared to what the suppliers do themselves, which means that retailers act as a marketing channel for the suppliers' brand. Direct selling has an advantage in that it creates experiences for consumers on a personal level. Finally, electronic commerce as a channel increases revenue and opens up for the possibility of storing large amounts of data.

The majority of the managers agree that the end consumers have preferences for the use of certain sales channels over others. However, this is based on personal speculation because none of the companies that participated in this study conducted any customer analysis. Instead, they assume that customers are satisfied with their brand mainly because of the quality that they offer. But, according to the theoretical framework, customer satisfaction is based on much more than quality. If companies are not aware of their competitive advantage compared to other companies, based on the end consumers' perspective, chances are that they do not exploit their advantages, which might lead to less customer loyalty.

According to the theory presented in the theoretical framework, it is obvious that many customers will cost more for the company to maintain than they contribute to the company's profitability. Customer profitability originates from customer loyalty, which arises from customer satisfaction. Since none of the respondents in this study have conducted cost-benefit analyzes, they do not have an accurate idea of how profitable their customers really are. Furthermore, the majority of the respondents have no accurate picture of who their loyal customers are. The companies that use e-commerce as a sales channel have done some follow-up on returning customers on an individual level, but this is mainly possible as the majority of them are still quite small. Should businesses grow, it will be more difficult for the managers to recognize who their regular customers are based on recognition of their names. What companies should keep in mind is that it may be essential for them to know who their loyal customers are if they want to have the opportunity to grow in this competitive market. Therefore, the managers first need to identify what makes their customers satisfied.

It is also important to acknowledge that the combination of sales channels often benefits the company. Obviously, various aspects need to be considered, e.g., how resource management will be done and if companies can manage to open up more sales channels considering the present skills and workforce. What should be taken into account is if the decision to not operate on multiple sales channels is based on fear that competition may arise between sales channels. It may be worthwhile to open up additional sales channels if it affects customer satisfaction, customer loyalty and profitability positively.

Since none of the companies in this study have conducted any customer analyses, no connection could be made between customer profitability, customer loyalty and customer satisfaction. If this study had been carried out on companies that use customer analysis, it might have given an insight as to how and if these companies benefit from customer analysis. Some of the respondents raised the issue that they see retailers as their main customers, although it is the end users who will use the clothes in the end. It would therefore also be interesting to examine what affects the relationship between retailers and suppliers has in the design and production of clothing. Even in terms of direct trade, the direct seller is considered to be the direct selling company's most important customers. It would also be interesting to investigate the problems that arise in this relationship.

\section{References}

Bell, D. R., Ho, T., \& Tang, C. S. (1998). Determining where to shop: Fixed and variable costs of shopping. Journal of Marketing Research, 35, 352-369. http://dx.doi.org/10.2307/3152033

Berglund, A. (2007). Direkthandelns kärna: säljmöten i många former. In E. Gummesson \& E. K. Ohlsson (Eds.), Direkthandel: en affärsmöjlighet i tiden: om den dolda distributionskanalen som globalt omsätter 750 miljarder kronor och engagerar 60 miljoner säljare (pp. 76-82). Malmö: Liber.

Bergström, F. (2007). Handelns roll och direkthandelns möjligheter. In E. Gummesson \& E. K. Ohlsson (Eds.), Direkthandel: en affärsmöjlighet i tiden: om den dolda distributionskanalen som globalt omsätter 750 miljarder kronor och engagerar 60 miljoner säljare (pp. 29-46). Malmö: Liber.

Boyce, G. (2000). Valuing customers and loyalty: The rhetoric of customer focus versus the reality of alienation and exclusion of (devalues) customers. Critical Perspectives on Accounting, 11, 649-689. http://dx.doi.org/10.1006/cpac.2000.0408

Chaffey, D. (2007). E-Business and e-commerce management: Strategy, implementation and practice. Pearson Education.

Coelho, F., Easingwood, C., \& Coelho, A. (2003). Exploratory evidence of channel performance in single vs. multiple channel strategies. International Journal of Retail and Distribution Management, 31, 561-673. 
http://dx.doi.org/10.1108/09590550310503294

Davis, R., Brodie, R. J., Lindgreen, A., \& Buchanan-Oliver, M. (2000). Pluralism in contemporary marketing practices. International Journal of Bank Marketing, 18, 294-308. http://dx.doi.org/10.1108/02652320010358715

Day, R. L. (1977). Extending the concept of consumer satisfaction. Advances in Consumer Research, 4, 149-154.

Foster, G., Gupta, M., \& Sjoblom, L. (1996). Customer profitability analysis: Challenges and new directions. Journal of Cost Management, 5-17.

Gensler, S., Dekimpe, M. G., \& Skiera, B. (2007). Evaluating channel performance in multi-channel environment. Journal of Retailing and Consumer Services, 12, 17-23. http://dx.doi.org/10.1016/j.jretconser.2006.02.001

Glynn, M. S., Motion, J., \& Brodie, R. J. (2007). Sources of brand benefits in manufacturer-reseller B2B relationships. Journal of Business \& Industrial Marketing, 22, 400-409. http://dx.doi.org/10.1108/08858620710780163

Gremler, D. D., \& Brown, S. S. (1999). The loyalty ripple effect: Appreciating the full value of customers. Industrial Journal of Service Industry Management, 10, 271-291. http://dx.doi.org/10.1108/09564239910276872

Guilding, C., \& McManus, L. (2002). The incidence, perceived merit and antecedents of customer accounting: An exploratory note. Accounting, Organizations and Society, 27, 45-59. http://dx.doi.org/10.1016/S0361-3682(01)00030-7

Helgesen, Ø. (2006). Are loyal customers profitable? Customer satisfaction, customer (action) loyalty and customer profitability at the individual level. Journal of Marketing Management, 22, 245-266. http://dx.doi.org/10.1362/026725706776861226

Hernant, M., \& Boström, M. (2010). Lönsamhet i butik: Samspelet mellan butikens marknadsföring, kundernas beteende och lokal konkurrens. Malmö: Liber.

Hoffman, D. L., \& Novak, T. P. (1997). A new marketing paradigm for electronic commerce. The Information Society: An International Journal, 13, 43-54. http://dx.doi.org/10.1080/019722497129278

Howell, R. A., \& Soucy, S. A. (1990). Customer profitability: As critical as product profitability. Management Accounting, 43-47.

Jones, T. O., \& Sasser, W. E. (1995). Why loyal customers defect. Harvard Business Review, 88-99.

Kalakota, R., \& Whinston, A. B. (1996). Electronic commerce: A manager's guide. Addison-Wesley Professional.

Kaplan, R. S., \& Cooper, R. (1998). Cost \& effect: Using integrated cost systems to drive profitability and performance. Boston Harvard Business School Press.

Kylebäck, H. (2007). Handel, handel vart är du på väg? Mölndal: BillesTryckeri AB.

Mahajan, V. R. S., \& Wind, J. (2002). The dot.com retail failures of 2000: Were there any winners? Journal of the Academy of Marketing Science, 30, 474-486. http://dx.doi.org/10.1177/009207002236919

Morgan, R. M., \& Hunt, S. D. (1994). The commitment-trust theory of relationship marketing. Journal of Marketing, 58, 20-38. http://dx.doi.org/10.2307/1252308

Mossberg, L. (2003). Att skapa upplevelser - från OK till WOW. Lund: Studentlitteratur.

Myers, J. B., van Metre, E., \& Pickersgill, A. D. (2004). Steering customers to the right channels. McKinsey Quarterly: McKinsey on Marketing, 4, 36-47.

Neslin, S. A., Grewai, D., Leghorn, R., Shankar, V., Teerling, M. L., Thomas, J. S., \& Verhoef, P. C. (2006). Challanges and opportunities in multichannel customer management. Journal of Service Research, 2, 95-112. http://dx.doi.org/10.1177/1094670506293559

Oliver, R. L. (1980). A cognitive model of the antecedents and consequences of satisfaction decisions. Journal of Marketing Research, 17, 460-69. http://dx.doi.org/10.2307/3150499

Oliver, R. L. (1999). Whence customer loyalty? Journal of Marketing, 63, 33-44. http://dx.doi.org/10.2307/1252099

Peterson, R. A., \& Wotruba, T. R. (1996). What is direct selling? - Definition, perspectives and research agenda. 
The Journal of Personal Selling \& Sales Management, 16, 1-16.

Peterson, R. A., Balasubramanian, S., \& Bronnenberg, B. J. (1997). Exploring the implications of the internet for consumer marketing. Journal of the Academy of Marketing Science, 24, 329-346. http://dx.doi.org/10.1177/0092070397254005

Porter, M. E. (2001). Strategy and the internet. Harvard business review, 1-20.

Powers, T. L., \& Reagan, W. R. (2007). Factors influencing successful buyer-seller relationship. Journal of Business Research, 60, 1234-1242. http://dx.doi.org/10.1016/j.jbusres.2007.04.008

Rådmark, H. (2009). Rätt väg till lyckad e-handel: En guide för både konsumenter och entreprenörer. Stiftelsenförinternetinfrastruktur.

Reichheld, F. F. (1988). Loyalty and the renaissance of marketing. Marketing Management, 2, 10-21.

Reichheld, F. F., \& Sasser, E. W. (1990). Zero defection: Quality comes to services. Harvard Business Review, $68,105-111$.

Rohm, A. J., \& Swaminathan, V. (2004). A typology of online shoppers based on shopping motivations. Journal of Business Research, 57, 748-757. http://dx.doi.org/10.1016/S0148-2963(02)00351-X

Söderlund, M. (1997). Den nöjda kunden. Malmö: Liber Ekonomi.

Söderlund, M. (2003). Den lojala kunden. Malmö: Liber Ekonomi.

Srinivasan, S. S., Anderson, R., \& Ponnavolu, K. (2002). Customer loyalty in e-commerce: An exploration of its antecedents and consequences. Journal of Retailing, 78, 41-50. http://dx.doi.org/10.1016/S0022-4359(01)00065-3

Vanraiij, E. M., Vernoiij, M. J. A., \& van Triest, S. (2003). The implementation of customer profitability analysis: A case study. Industrial Marketing Management, 32, 573-583. http://dx.doi.org/10.1016/S0019-8501(03)00006-3

Venkatesan, R., Kumar, V., \& Ravishanker, N. (2007). Multichannel shopping: Causes and consequences. Journal of Marketing, 71, 114-132. http://dx.doi.org/10.1509/jmkg.71.2.114

Wallace, D. W., Giese, J. L., \& Johnson, L. L. (2004). Customer retailer loyalty in the context of multiple channel strategies. Journal of retailing, 80, 249-263. http://dx.doi.org/10.1016/j.jretai.2004.10.002

Wolk, A., \& Skiera, B. (2009). Antecedents and consequences of Internet channel performance. Journal of Retailing and Consumer Services, 16, 163-173. http://dx.doi.org/10.1016/j.jretconser.2008.11.010

Yi, Y. (1990). A critical review of consumer satisfaction. In V. A. Zeithamn (Ed.), Review of Marketing, American Marketing Association (pp. 68-123). Chicago.

\section{Copyrights}

Copyright for this article is retained by the author(s), with first publication rights granted to the journal.

This is an open-access article distributed under the terms and conditions of the Creative Commons Attribution license (http://creativecommons.org/licenses/by/3.0/). 